\title{
2014年度 書評
}

日本政治学会書評委員会

\section{政治理論}

対象 井上彰, 田村哲樹編『政治理論とは何か』風行社, 2014年 早川誠『代表制という思想』風行社，2014年

かつてグラッドストンはディズレーリとの口論中，興奮のあまり両者の あいだにあったテーブルを吒いてしまい，机上の文房具が床に落ちた。デ イズレーリはそれを静かに拾い上げつついわく，「貴下と余のあいだにテ ーブルのありしことを神に感謝す」。このエピソードを紹介しながら深瀬 基寛は「二大政党の転換の原動力がこのユーモアにあることを果して政治 学者は気づいているであろうか。ユーモアこそ議会政治の文学的本質なの だ」と述べている。

政治学者にかぎらず，世間一般的にもこの主張に首肯する人は多いので はないか。しかしこれが政治学的な命題として成立するかどうかは別問題 である。さらにそれが世間一般を納得させている理由を深瀬の「論理」や 「文体」に求めることは可能だろうが，彼の「方法」あるいは「理論」だと することは難しいだろう。その困難の理由を考えると，そこには政治に関 する思惟とその方法をめぐる特殊性（という表記の問題点についてはひと まずおいておく）が浮上する。この問題に関して重要な視座を提供する対 照的な二著について論じたい。

『政治理論とは何か』では表題どおりのテーマが複数の論者によって多 角的な視点から論じられている。ラズレットによればロールズの登場以降, 「政治理論は死んた」のだ，そうした状況にもかかわらず，多くの政治学 者がそれぞれの政治理論を構築しようとしている。それは一種の「なんで もあり」的な状況である。だからこそ政治史から比較政治，地域研究，国 際政治，数理分析までのあらゆる関連領域を政治理論は攪乱し，統一され た政治理論の不在を前提に政治学の体系そのものを批判し続けるというゲ リラ行動にこそ政治理論の価值があるともいえる。 
本書ではそのような多様性を認めたうえで，それでもなお政治理論の統 一的な進展の可能性を構想している。そしてそれを以下の三方向に求める。 政治理論の類型化，方法論（あるいはその欠如）の考察，自己批判の深化 である。本書においてその三方向は十全に論じられている。しかし次の問 題はそれで本当に政治理論の進展は可能なのかということである。そうし た問題に対応すべく本書には政治理論の外部からの批判も複数収録されて いる。政治思想史，経験的政治学といった政治学内にとどまらず，規範経 済学, 法哲学, 社会理論などの政治学外からの批判である。

政治学内からの批判である河野勝による「『政治理論』と政治学」におい ては，従来の政治理論に対する全否定とさえいえるほどの論説が展開され ている。河野によれば，政治理論は政治学の他領域において発展している 方法と方法論についてあまりに無知，無関心であり，さらには政治理論と いう呼称自体が虚偽的で本来は規範分析と呼ぶべきものである。河野が使 用する方法や理論といった用語の規定について異論はあるだろうが，重要 な批判であることは疑いない。

また政治学外からの批判である盛山和夫による「政治理論の応答性とそ の危険」では, 政治理論が理念研究に埋没しており, そのことが結果的に 現実との有意な応答を忌避するような「脱政治的」なディシプリンとなっ ている点が批判されている。政治的共同体における秩序維持という重要な 問題に関する「構想としての政治理論」が欠けているという指摘である。

もちろん本書においては他の章がこうした批判に応答している構成にも なっているので，政治理論側からの反論にも接することはできる。たとえ ば田村哲樹は第 2 章「政治／政治的なるものの政治理論」において，政治 理論の自己洞察の進展は政治現象の検討と連続であることを示し，政治理 論が政治学の他領域と関連する意義を強調している。

こうした多数の研究者間の（場合によっては激しい）議論の応答はもち ろん政治理論にとって非常に有益である。しかし政治理論についての異な る様式の研究もまた有益であり, その様式の差異について考察すること自 体も政治理論の発展の一助となるだろう。『代表制という思想』はそうした 例である。本書は当該テーマに対して一人の研究者が沈思黙考した結果で ある。

本書の主張は非常に論争的であるものの，シンプルである。代表制は政 
治体の規模が巨大化したために直接民主制の代替物や次善策として導入さ れた必要覀ではなく，代表制は本来的に民意を反映しないという特性によ って民主主義を活性化させる貴重な制度である，というものだ。

まず著者は首相公選制を例にしながら直接民主制についての理念的再検 討から議論を開始する。続いて「熟議」「代表」「議会」といった概念が八 一バーマス, ピトキン, シュミット, シュンペーターらのテキストの精緻 な読解によって整理，再構成され，上記の結論へと至る。

こうした代表制に関する主張は非常に重要であるものの，本書の特徽は 以上のような代表制の再定義自体にあるのではない。同様な代表制の解釈 は著者も引用するバークをまつまでもなく，政治思想の領域ではいまだ議 論対象ではありつつも，格段に少数派の意見というわけでもない。本書の 政治 (学) 上の例外的意義は, これが叢書として一般読者を対象として出 版されているという点にある。巻末に索引はあるものの, ほとんど注もな い本書の性質は，体裁のみが一般書のものだということにとどまらない。

注目すべきは「代表制は直接民主制の代替物である」という世間一般が 考えるであろう認識を一方的に誤謬と措定したうえで，それを専門研究者 である著者がいとも簡単に切り捨てているということである。さらにはこ の究極の啓蒙主義的な手法を民主政治に関する書籍においてまったく臆す ることなく披瀝しているという点こそが本書の特徴となっている。

代表制の解釈について評者自身は著者の主張に同意する。しかし世間で の認識を俗説として全否定してよいかどうか，これもまた別問題である。 著者は「はじめに」において,「どんなにわかりやすく説明できても研究対 象そのものの複雑さが消元去るわけではない」という専門研究者としての 開き直りともとれる表現を残しているが，この表現は著者があきらかに専 門研究者以外の読者を想定していることを示している。また実際の読後感 は別にして，著者によれば「あちこち回り道をしながら考え考え書いてい る」とのことであり，それにのんびりとつきあうよう読者に要請もしてい る。

自律的で主体的な市民という主体を前提概念とせざるをえない現代政治 (学)に扔いて，このような表面的なエリート主義は誤解を招きやすい。特 にシュンペーターについての記述においては, 読者が強引に行間を読まざ るをえないほどの境界的で危険とも思える解釈が展開されている。この種 
の危うさは先に紹介した『政治理論とは何か』には皆無である。こちらの 書籍に一般市民が接する可能性はほぼ皆無であり, 各章の論者は専門研究 者のみを読者対象とし，誤読などありえないような明晰な文章を書き続け ているからだ。

こうして二著は対照的な色合いを見せる。専門書と一般書, 共同討議と 個人的思索，同時代的著作による現代性の確認と過去の思想への遡行的確 認，そして専門科学としての矜持と啓蒙主義としての教説。これらの対比 から私たちは多くのことを政治学，あるいは政治理論の特質として議論し うるだろう。

たとえば『政治理論とは何か』に見られるような専門研究者間の意見交 換は当該領域の学術的進展には不可欠である。しかしそれが自分が属する 学問領域の独善的な正当化に終始するのか, それとも当該領域を含めた学 問全体の発展に結びつくのか。本書が市民一般から断絶されているように 見えても，この点についての回答は結果論として市民社会から提示される しかないだろう。

『代表制という思想』に見られるエリート主義的啓蒙についても，この方 法をとることによってのみ現在の市民社会において民主主義を活性化でき るはずだという著者の信念は貴重であるし，尊敬すべきである。しかし啓 蒙の可能性を保証する内実としての学問的水準を政治理論全体は維持でき ているのか。それについては『政治理論とは何か』のような類の研究なく して保証されえないだろう。

およそ政治学者が同時代的に現実政治に役に立ったことはおそらく人類 史上ないといえようし，そのことが政治学の特殊性として説明されるほう が，少なくとも政治学においては一般的でさえある。いわんや実社会にお いてをや。当然のことだが政治学がなくても市民は生きていくし, 政治学 者がいなくても政治家は活動しつづける。そうした状況で政治学はどうあ るべきか。前記した深瀬基寛の直観にちかいアネクドートの解釈を政治理 論が超えるための思索として二著は高く評価されるべきである。 


\section{政治過程}

対象 伊藤光利・宮本太郎編『民主党政権の挑戦と挫折

\section{その経験から何を学ぶか』日本経済評論社，2014年}

民主党が2009年 8 月，衆議院議員選挙に勝利して，3 年 3 カ月の間に 3 人の総理大臣を出した。政権を自民党に奪還されたのが 2012 年の 12 月だっ たので，そろそろ，この民主党政権の 3 年 3 力月の評価を行㧍うという機 運が醸成されたということか, 近年, 多くの書籍が出版されている。当事 者自身の述懷や研究者による当事者への聞き取りを記したものも多く出て いる。民主党の政治家の稚拙さによる失敗を語るものが多い中，この書評 で取り上げょうとしている伊藤・宮本編は，少し趣を異にしている。

序の冒頭に記されているように，本書は「民主党政権は何に挑戦し，何 を達成し，なぜ失敗し，いかなる教訓を残したのかを構造的かつ実証的に 検証」し，「今後のわが国の政治のあり方として，リベラリズムの行方とい う観点から，新たな政治対抗の可能性を検討」することを目的に書かれて いる。特に，55年体制と呼ばれる長い自民党一党優位のもと，打ち立てら れてきたいわゆる「土建国家」レジームのアンチテーゼとして何を提起し ようとし，それはどの政策にどのように見て取ることができ，そうした政 策はどの程度まで成功し，何が不十分だったのかを分析することにより， 「リベラリズム」と彼らが語るところの新しい体制を巡る新しい対立軸の あり方を見ようとしているところが本書の特徵であろう。そういう意味で は政治過程論の守備範囲を超えて，レジーム論，体制論を視野に入れた研 究であると言える。

言い方を変えれば，民主党政権は失敗であったとしても，そこから日本 政治の将来のために救いだせるものはないのかを見極める作業を，意図的 に行おうとしている点が本書の特色であると言える。もちろん，数々の失 敗の指摘も行い，その意味では点数が甘いということではないが，落第の 政権と切って捨てているわけではなく，新たな政策選択，政治的体制選択 のとば口に立つところまではきていると見て，その可能性に言及しつつ， 再度の挑戦があるとすれば，この失敗から何を学ぶのがよいのかという問 題意識で書かれていると言える。したがって，この書評でも，民主党政権 は，従来の自民党一党優位体制下の日本政治のありように対して，何を問 い，何をぶつけたと説かれているのかを見ていくことになる。 
民主党政権が何に挑戦したのかについては，明瞭に書かれているように， 「土建国家」と呼ばれるレジームに対してであり，これに，「リベラル」な あり方をぶつけたと記されている。ただ，このどちらもが，ややポレミカ ルな語で不分明なところがあり，一方をやや否定的に，他方をやや肯定的 にとらえているようだということだけは分かるかもしれないが，分析的に 読みたい読者は，ここで投げ出しかねないと感じなくもない。もちろん， 著者たちはそのあたりは百も承知のようで，しばらく読み進めば丁寧な言 い換えにつきあたる。

「土建国家」とは，日本型生活保障の型であり，政治·行政が経済政策と 公共事業を通じて業界を保護し，男性稼ぎ主の雇用を安定させ，その男性 稼ぎ主が妻と子を養うシステムを指しており，自民党一党優位体制の下で この体制は政・官・民をつらぬく安定的ネットワークを有することになっ たとされる。したがって，これに挑戦するためには，日本型生活保障の型 を変容させるための政策を提起するだけでなく，政策形成・実施のネット ワークを作りかえることも提起しなければならないことになっており，民 主党はこれにも手を付けたとされている。まさに「構造・理念・戦略」を それぞれ見なければならないというわけである。

「土建国家」の対抗理念として出される「リベラリズム」はさらに厄介な 語で，多義的である。「民主党の理念は，単一ではなく，方向の異なるリべ ラリズムの混合的集積物」とされ，古典的自由主義はもちろん，戦後和解 により誕生した福祉国家のイデオロギー，これを批判した新自由主義を含 み，「自立と共生」というスローガンが含む「リベラリズム」はこの曲節か らも少しはみ出しているだろう。伊藤がこのように多義性の説明を行った 後，著者たちが「現代リベラリズム」という呼称で何を示そうとしている のかについての丁寧な説明は，宮本による最終章まで待たされることにな るので，本書の問いを，民主党が自民党のこれまでの何に何を対置したの かというところに置かれていると読んだとしても，民主党の対置したもの， 著者たちが評価して日本政治のために救い出したいものの正体について， いぶかしさを抱きながら読まねばならないことになっている。「構造・理念 ・戦略」を各章の分析を貫く骨格であるとしているのだが，読者は，民主 党の理念のおさまりの悪さを引きずりながら読むことになる。民主党政権 を単に失敗として片づけている他の著作は，ここに悩むことはないのでわ 
かりやすいところがあるが，民主党自身が明瞭に語れていたかどうか怪し いところを，できるだけ好意的に汲み取ってやろうとする本書の苦しさが ここに現れている。

しかし，単に政治家個人の力量の問題として片づけられないものが，こ の政権交代にはあると見て，行き詰まった体制の転換への挑戦と見ようと した著者たちの試みは成功している。民主党の政治家たちが実際にできて いたかどうか，語れていたかどうかではなく，彼らが何に直面していたか という意味で，すなわち行き詰まりを示していた「土建国家」レジームを どのように変容させていくかという課題に向き合っていたのたととらえた とき，この視点から彼らの行動を，政策を読み解いていくことは重要であ ると悟らされることになる。また，そう考えると，政権を取り戻した自民 党が，この課題にどのように向き合っているのかも見ていかねばならない ことを示している。そういう意味で，現代日本政治に関心のある者が向き 合わねばならない課題を提示したと評価できると思われるのである。

最終章で宮本が示している「再分配原理」対「市場原理」の軸と「個人 ・自律」対「権威・秩序」の軸を独立と見立てた「政党政治の対立軸と現 代リベラリズム」という図が問われていくべき一つの課題であろう。自民 党は「再分配」・「権威」フィールドから「市場」・「権威」フィールドに移 行したと思われる。民主党が提起しょうとしていたのは「再分配」「個人」 フィールドのレジーム建設だと見ようというのが宮本の見立てであり，こ れは経済のグローバル化にさらされ，困難に際会しているということであ るが，この両軸の独立性自体にも疑義がないわけではない。再分配は権威 的な価值剥奪なしには考えにくいからだが，彼らが「現代リベラリズム」 と呼ぶものは，この両立しにくそうに見えるものを両立するかのように見 せることだと気づかされる。「自立と共生」が語っていたのはこの困難さ であり，これを両立するかに見せるヴィジョンを示す力量，リーダーシッ プが民主党の政治家たちにはなかったということかと頓悟するのである。

自民党が，権威主義的に再分配を行ってきた体制を捨て，権威主義的に 強者を守り，彼らの間で自由を謳歌する体制へと移行したのだとすれば， このある意味ではとてもわかりやすい政策指向に対し，これに対抗する側 は権威的な再分配を権威の臭みを感じさせず行うという，困難な課題が突 きつけられていることになる。この課題を示すためのシンボル的な言葉が 
見つからないことが「リベラリズム」という意味の定めにくい言葉を使い 続けることになっている理由だろう。

一強多弱の体制といわれる。政治的対抗軸のありようについての著者た ちの見立てが正しいとすれば，確かに，「自立と共生」を掲げる政治勢力が 健全な日本政治の対抗軸の一方に必要であろう。それを現在の民主党の残 存勢力に期待できるかどうかは別問題だが。

\section{行政学・地方自治}

＜評者 外山公美 $>$

\section{対象 千草孝雄著『アメリカの地方自治研究』志學社，2013年}

本書は 2 部15章で構成されており, 全451頁に及ぶ大著である。また, 本 書は著者がこれまでに執筆した論文を再構成したものであり，その意味で も著者の研究成果の集大成ということができよう。このような本書の性格 上，まずは部章別に論点を整理することにしたい。

第 1 部「グッドナウの地方自治論」においては，まず序説でこれまであ

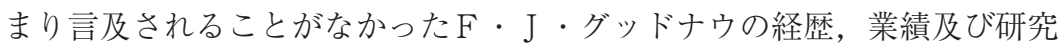
史について述べている。彼の主著といわれている『政治と行政』に表れて いる基礎理論と彼の地方自治論との間には「いろいろなずれ，差異，矛盾」 があり，これらを子細に点検し考察することによってはじめてグッドナウ の思索の跡とその学説の個性を解明することが可能となるとしている。こ れに基づき，第 1 章で『政治と行政』を通してグッドナウの基礎理論を詳 細に考察したうえで，第 2 章では彼の地方自治論の構造を解明し，基礎理 論との関連にも言及している。また，第 3 章では，市政改革運動とグッド ナウの関係について, 特に彼が作成に関与した第一次都市綱領とその後に 作成される第二次都市綱領を比較することを通じて考察している。以上の ような考察を通じて, 著者は第 1 部の結語において「グッドナウの存在な しにはありえなかったかもしれない改革要素」として「世紀末転換期の時 点において市会の強化を提言し，市会の復権と再生への途を拓いたこと」 を指摘している。

第 2 部「アメリカの地方自治論」では，まず，第 1 章において，第 1 部 の考察をふまえて，市政改革運動に関する行政学上の研究経緯を再整理し， 論点の整理を試みている。第 2 章及び第 3 章においては, アメリカの都市 政府形態に関する考察がなされている。第 2 章ではこれまでアメリカやわ 
が国において研究の対象として取り上げられることが少なかった委員会制 を手がかりとして，アメリカの都市政府形態論について再検討を加え，第 3 章では市支配人（=シティ・マネージャー）制に関する J・H・スバラ の研究を紹介しつつ, 現代アメリカの都市政府の政治構造，行政動向を考 察している。第 4 章では, アメリカの全国都市連盟のモデル都市憲章につ いて, $\mathrm{H} \cdot \mathrm{G} ・$ フレデリクソンの研究を参考にして分析している。第 5 章 では，前章でも言及したフレデリクソンの都市政府形態論を中心に彼の提 唱するモデルを考察している。第 6 章〜第 8 章は第 2 章でも言及したカウ ンティ政府について論じている。著者の指摘によれば，20年ほど前から同 政府を重要な研究対象としている研究者が現れてきているという。カウン ティ政府の変遷や特質，その研究の状況を第 6 章で考察し，同政府が直面 する現代的な問題や課題については第 7 章及び第 8 章で分析が加えられて いる。第 9 章では, フレデリクソンと J ・ナルバンディアンを編者とする 文献を紹介し，アメリカにおいて地方自治研究が大きな進展をみせている ことを解明している。第10章及び第11章は，第 4 章でも取り扱ったモデル 都市憲章の最新版である第八次憲章についてその成立の背景やプロセスに ついて考察することを通じて, 現代アメリカの地方自治論について言及し ている。最終章となる第12章「行政学説史に関する若干の考察」では, 本 書での議論をふまえながら， T・W・ウィルソンの学説史上の位置づけに ついて第 1 部で論じたグッドナウとの比較をも考慮しつつ考察している。

以上のように，まず第 1 部では，グッドナウに焦点をあてて市政改革運 動について検討を行っているが, その検討の過程でグッドナウの行政学説 史上の役割について，わが国の行政学者による見解も紹介しつつ, 考察し ている。著者により1989年に執筆された論文の再掲であるが，原点に立ち 戻った大胆かつ緻密な分析は, アメリカ行政学の誕生や政治行政二分論を 再考するうえでも重要である。

第 2 部で注目すべきはアメリカ都市政府形態の新動向への考察である。 この都市政府形態については強力市長制，弱力市長制，委員会制，市支配 制の 4 つを中心とした類型化が長い間支持されてきたが，現在では，多様 化・複雑化が進展し, 再構成への必要性が生じている。本書における第 3 章，第 5 章及び第 9 章もこの新動向を裏付ける内容となっている。すなわ ち, 第 3 章では, スバラが使命, 政策, 行政, 管理という 4 つの概念に着 
目し, 市議会と支配人との関係を強力支配人型，市会優勢型，市会侵入型， 市会・支配人孤立型の 4 つに類型化して同制度を細分類化したことに注目

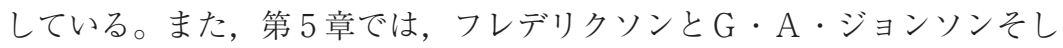
てC・H・ウッドの共著として刊行された『適合都市 (The Adapted City)』 において提唱されたモデルについて論じている。このモデルは，アメリカ の都市政府形態が強力市長制と支配人制に二極化していることに注目し， 前者を政治的都市，後者を行政的都市と両極に位置づけ，政治的都市が行 政的都市の要素や特徵を取り入れたものが適合政治的都市であり，その逆 を適合行政的都市とし，さらに政治的都市と行政的都市の基本的原則と論 理が完全に混ざり合ったものを融合都市としている。著者はこのフレデリ クソンらの研究を「アメリカの都市政府の形態に関する卓越した研究」と して高く評価している。さらに第 9 章では, 『地方政府の未来（The Future of Local Government Administration)』に掲載された論文のうちスバラの執 筆した首長，議会と市支配人や首席行政官の関係をめぐる 2 本の論文につ いて検討している。このような動向は，著者も指摘するようにアメリカ都 市政府形態の分析についてより細かな研究や新しい視点の必要性を示して いるといえよう。

本書全体を通じて, 斬新な切り口からの多角的な考察がなされ, 緻密な 文献・論文研究を中心とした分析がなされている。著者も言及しているよ うに，インターネットなどの発達によりアメリカ地方自治の研究方法も大 きく変化している。著者の文献・論文研究とインターネットなどによる情 報収集を中心として本書が執筆されていることは，フィールドワークや現 地ヒヤリング調査を主たる方法として同分野を研究している評者にとって は敬服に值するものである。また，委員会制やカウンティ政府などこれま で研究対象として取り上げられることが少なかった，いわば盲点とでもい うべく諸制度が本書において検討されている点も特筆すべきであろう。わ が国でも地方公共団体における長と議会の関係や二元代表制の意義を再検 討する動きがでているなかで，本書の役割は重要であるといえよう。

しかしながら，構成面では前述のように，本書が著者のこれまでの論稿 によって構成されていることもあり, 極めて広範な内容となっており, 章 構成にもやや不自然な部分があることは否めない。特にアメリカ地方自治 制度の新動向を取り扱う第 2 部において, 著者の見解を纒めた本書のため 
の書き下ろし論文を期待するのは評者だけであろうか。

昨年, 本書でも触れられている ICMA (International City/County Management Association）は設立100周年を迎えた。ノースカロライナ州シャーロ ットにおいて開催された記念大会に，評者も出席し，市支配人や首席行政 官との交流を通じ，アメリカの地方政府形態の多様化・複雑化を実感した ところである。変革の波が押し寄せているアメリカの地方政府を著者と共 に見守りたいと思う。

\section{政治思想史（欧米）}

\section{<評者 佐藤正志 $>$}

\section{対象 宇羽野明子『政治的寛容』有斐閣, 2014年}

今日，公共的領域と宗教の関係が極めて深刻な問題をグローバルに引き 起こしている。それについての共和主義的な解決とリベラルな解決，また 前者のフランス的特有性も重要な論点となってきた。本書は, そうした議 論を政治思想史的淵源からの考察に立ち返らせてくれるであろう。

本書は，モンテーニュを中心に16世紀の政治思想を研究してきた著者が, 当時の寛容思想を近代的寛容思想の源泉として解釈することに疑問をもち， それを「政治的寛容」として理解しようとした試みである。ここで近代的 寛容思想とは，良心の自由にもとづき異なる宗教を受容する宗教的寛容で あり，それに対して著者が「政治的寛容」(la tolérance civile) として対置 するのは，公共の秩序と平和の維持という政治的理由により暫定的に国内 で 2 つの宗派を受容しようとする寛容思想である。当時の寛容思想とは, まさしくそのようにして是認しがたい存在を暫定的であれ共生の対象とし て受容しようとするものであったことが強調される。

こうした視点の転換は, 伝統的には, 積極的な道徳的価值として宗教的 自由への確信をもつ人々ではなく，ただ戦に対する唯一の代案として， 譲歩する必要性を不運にも認めざるを得なかった人びとによる暫定的受容 として過小評価されてきたもの（この例として，Q.スキナーの解釈）を再 評価することを意味する。

従来, 政治的寛容は, アナーキーな状態から秩序を創出するために絶対 的権力を擁護する立場と考えられてきた。その背景には，一方では，策略， 欺瞞, 脅迫といった実際の政治の世界を提示して国家の「必要性」の問題 を焦点化し, 非常時には, 統治者が道徳を無視することを要請するタキト 
ウス主義の台頭，他方で，個人に対しては教条主義，狂信主義からの個人 の内面的自由を確保するために，公的服従と宗教的，道徳的コミットメン トの留保を促す新ストア主義と懷疑主義があった。そこに，絶対主義の秘 薬を隠し持つために「公」の思慮が，そして，市民を個人の内面という要 塞に匿うために「私」の思慮が現れることになったとして，その文脈での 寛容の孕む危険が指摘されてきた。そこでは，宗教や道徳的信念が相対化 されるとともに，それらから自由になるアタラクシアの境地が模索され， その反面で，外面上の，国家への服従が絶対化され，抑圧的な絶対主義国 家がもたらされたのであると（例えばR.タックの解釈）。

しかしこうした解釈は一面的であると著者は主張する。公的服従，外面 的服従の要請はたんに宗教や道徳的信念から自由になるために要請された のではない。良心への強制によって生じる無秩序，また良心を根拠にした 抵抗によって生じる無秩序に対して，信仰の一体性を欠いた状況のなかで いかに秩序を回復させるかが課題となったその時に，「政治的なるもの」が 問われたのである。そこでの服従要請の際の正当性の議論が，良心との関 係に拈いて展開され，良心との関係から「政治的なるもの」が考察された ことの意義を著者は重視する。本書を通じて, 著者は, 政治と良心の関係 が問い直されるなかで「政治的なるもの」の諸相が浮き彫りとなってくる 過程，そのようにして「政治的なるもの」が自覚化されてくる過程を，最 近の研究を参照しつつ, 当時のテクストに語らせることによって描き出し ている。

この読解を通じて，著者は，この政治的寛容における政治的なるものを 「シヴィリテ」の伝統に見出す。伝統的にアリストテレスまで遡る「シヴィ リテ」の概念は，もともと人間の固有性である「共同の生」を，政治社会 の「法」と社交の「作法」を通じて成り立たせ，秩序づけるための原理で あり，技術・知識を意味した。16世紀フランスでは，フランス王国の統治 原理が「法のシヴィリテ」として表現され，それは，ローマ法上の法秩序 保全原理を，また法解釈（市民法に従い理念と現実，理論と実践を結びつ ける）の技術と知識を意味したことが明らかにされる。そこで，統治原理 としての「シヴィリテ」は，共生のための政治技術に体現された「衡平」 原理となる。

政治的寛容を支持し，推進した者の多くは法に携わる者たちであり，彼 
らの法・国制観には，マキアヴェッリ的なものや絶対主義的なものではな く，つねに「シヴィリテ」による王国統治の優秀性が表現されていた，と 著者は指摘する。16世紀の政治的寛容とは，伝統的国制に依拠しつつ，王 国の共通の紐帯としての「法」の下での（「真の宗教」の下でではなく）, 「政治的なるもの」による暫定的な共存に向けた実践そのものであった。

宗教上の多元性を承認したうえで，対等者間の水平的な関係として成立 するものを「積極的寛容」と呼ぶとするなら，それは，最終的な目標を宗 教上の「共和・一致」, すなわち「宗教上の再統一」としながら, 暫定協定 としての政治的寛容であったという意味で，「消極的寛容」にとどまり，本 来的には共生不可能で排除すべき「悪」を，共生可能なものとしてその存 在を法的に許容してゆこうとするものであり，支配者から被治者に向けた 便宜性にもとづく一時的政策にすぎないものであった。しかし，当時の宗 派間共存の試みは，不寛容の抑制として，まさに法＝政治領域の自律によ る実践（「政治的実践の世俗化」）であったことにこそ着目すべきであるこ とを著者は強調するのである。

上記の主張が，最初に，16世紀フランス政治思想における国制論に表現 されたシヴィリテ概念の抽出, 続いて, 良心論と寛容論との関わりの議論 中に見出される法のシヴィリテ，最後に，そのシヴィリテ観からのモンテ 一ニュ政治思想の再解釈と続く本論を通じて裏付けられていく。とくに, モンテーニュをめぐっては，従来，懷疑主義から帰結する国家理性の擁護 として解釈されてきた公的服従の要請について，著者はそのシヴィリテ観 からの解釈を提示している。それによれば，モンテーニュは既存の法＝政 治秩序がシヴィリテの伝統とかけ離れた現実においても，なお，その伝統 に依拠してその秩序再建を目指し, しかも各人の衡平（自らの内なる法と 法廷，つまり良心）の確立を通じて共同体全体の衡平の回復を目指したの であるとされる。そのようにして，共同の同意による既存秩序の保持とい うシヴィリテの伝統を踏襲しつつ，衡平の実現をまず各人の良心の法の下 に置くことで，各人がその良心に従い，多様な生の受容を可能とする法＝ 政治秩序の構築を目指した点にこそ彼の政治的寛容の独自性があることが 強調されるのである。

是認しがたい存在を暫定的であれ共生の対象として受容しようとする政 治的寛容は，政治思想として研究を掘り下げるのに十分值するテーマであ 
るとする著者が，そこに思想史研究のテーマ以上の今日的課題を見出して いることは想像に難くない。

寛容とは，従来，価值の多様性の支持など，その理念にもとづく哲学 的原理から理解される傾向にあった。しかし，その歴史的考察が示唆 するところによれば，寛容は本質的には，共同の生を前提とする法= 政治的原理に，とりわけ政治的技術・実践知に依拠するものといえる のではないか。本書での以上の考察から明らかにできたことは，当時 の政治的寬容が，共生のための秩序をなすために，むしろ「暫定的」 であるからこそ，現実の具体的諸状況にいっそう適切な共存のありよ うを追求することができたということである。したがって，それは 「政治的なるもの」による平和的共存, シヴィリテによる共生として評 価されるべきであると考える (同書，200-201頁)。

本書では，著者は政治的寛容を理解することに徹するとされており，そ れが寛容の思想史においてどのように位置づけられるのか，フランスにお ける啓蒙の寛容思想からライシテまでの歴史における位置づけ，またリべ ラルな寛容論の成立とのかかわりなど，興味深い問題が後に残されている。

そうした課題に関連して, 初めて邦訳されたホッブズの『ビヒモス』（山 田園子訳，岩波書店，2014年）が大変興味深い。ホッブズも，もっぱら公 共の秩序と平和の維持という観点から，公共的領域としての国家の宗教か らの自律をはかったが，それは，シヴィリテの伝統（法の支配にもとづく 混合君主制）を否定する国家主権の確立を通じてであった。衡平は主権者 の命令である法への服従とされ，公的領域は良心との緊張を失い，主権は 絶対化されたが，それによって個人はそれぞれの魂に介入されることなく 保護されることになるのである。逆に宗教的教義が個人の魂に介入して公 的領域を解体していったイングランド内乱の経過をたどったのが本書であ る。

ホッブズの主権概念を転倒し，法の支配する共和国として公共的領域を 再構築しようとしたのがルソーである。そこでの一般意志の概念のテキス 卜形成過程に即した分析，ルソーの属する共和主義的伝統の分節化，公共 的領域を支える情動としての公論の考察など，極めて示唆に富んだ研究が 
初めて邦訳で紹介された。ブリュノ・ベルナルディ『ジャン＝ジャック・ ルソーの政治哲学一一般意志・人民主権・共和国』（三浦信孝編，永見文雄 ／川出良枝／古城毅／王寺賢太訳，勁草書房，2014年）を通じて，市民宗 教を提示したルソーに拈ける，良心と公論に根ざした，公共的領域に掞け る普遍性と個別性の間のジレンマの乗り越えの試みを捉え直しながら，政 治的寛容の構想の可能性を考えてゆくこともわれわれに残された重要な課 題である。

\section{政治思想史（日本・アジア）＜評者 安西敏三> \\ 対象 濱野靖一郎著『頼山陽の思想一日本における政治学の誕生一』 \\ 東京大学出版会, 2014年 \\ 小寺正敏著『幻視の国家一透谷・啄木・介山，それぞれの，<居 場所探し>ー』萌書房, 2014年}

頼山陽といえば，『日本外史』であり，それは「王政維新の元素」（福澤 諭吉）と，思い浮かべる人も多いであろう。あるいは「尊皇攘夷の声四海 に遍かりしもの，奚ぞ知らん彼が教訓の結果に非ざるを。鳴呼是れ頼襄の 事業也」(山路愛山）に肯く歴史好きも居るはずである。然しながらその末 尾に著されている「徳川氏論賛」を読めば，そうでなくとも忠臣楠氏を差 し置いて徳川が祖とした新田氏を正記としていることなど，あるいは何よ りも老中首座を勤めた松平定信に謹呈していることなどを勘案するならば， 「現実の支配体制にとって危険な書物でなかった」(尾藤正英) ことは確か に明らかであろう。幕末から明治にかけて広く読まれた『日本外史』では あるが，それは同じく『日本政記』と共に，当時の私塾の教科書ともなっ ており，それらの影響力は推して知るべしである。頼山陽が当時の思想を 観る上で無視できない所以である。さらに『外史』と共に自らの代表作と 位置付けた『通義』を加えて，文人山陽も含めて既存の山陽像を根本的に 転回させ政治学者山陽を前面に押し出した野心的な試みとなっているのが 濱野靖一郎『頼山陽の思想』である。その叙述は然し大胆に終始している 訳ではない。堂々たる学術書に相応しく理論構成は精緻であり高尚である。 江戸思想史は言うまでも無く，中国思想史をも踏まえての微視的であると 同時に巨視的な視点で以て頼山陽の思想を分析しているのである。まず既 存の山陽像を誤解の重層として紹介寸る。それには時代が反映しているこ 
ともあり，時代が下るにつれて「尊王攘夷」論者山陽から「文人」山陽に ベクトルが移動していることを指摘しつつ，これまでの政治理論を踏まえ ない山陽論を批判し，三部作『日本外史』『日本政記』『通義』を主として その政治理論の解明を試みる。それが為に山陽以前の思想史的問題として 中国に㧍ける「権」「理」「法」の正統論の系譜が, 蘇軾, 朱喜, 方孝孺を 取り上げて, 山陽研究の文脈から検討される。次いで日本における政治学 の源流として熊沢蕃山, 荻生徂徠, 太宰春台, 尾藤二洲を挙げ, 頼山陽に おける「君主論」の成立で以て日本における政治学の誕生を打ち出す。こ こで重要なのは国家の治乱を左右する「勢」である。それが山陽の統治・ 歴史理論の中核概念であり，その思想的営為は東アジア思想史上画期的で あるという。「勢」において如何に「権」を把持するかが政権維持の鍵であ り，そこから「機」を窺い「利」を保つことの必要性が説かれる。結果本 位的功利主義が東アジア思想の特徵と言われるが，そうした側面を持つ儒 学に反して「利」を根本に据えた政治観を打ち出したのが山陽であるとい う。利己心からモラリティーの成立を説くのである。利已心を活かしての 国家破綻に陥ることのない「機」, 即ち制度的仕掛けが必要となる。そこに 「権」の保持者君主の役割もある。物事の軽重を計り決定する機能として の「権」である。仰ぎ見る存在ではなく統治機構内部における機能の面か ら定義される君主である。東アジア政治思想史上画期的な論である。そう して山陽君主論にとって「人命至重」が重要視される。しかも史的事実を 論拠として統治論を抽出する政治学者山陽によれば，それは法律の精神で あり，政治の根底である。「至重」である「人命」が「民」のそれであるこ とも重要である。統治の中心に「民」を置くが故にその「人心」の承認が 「天道」を超える統治の正統の正統たる所以となる。君主の決断と責任も 「民」の「人心」如何にある。それに背かなかった徳川政権こそ称えられる ものであり，その正統性を論理的に構築したのが『日本外史』である。そ の結びを読むものにとって正当な解釈を著者は提示しているのである。そ れでは山陽評価の思想史上のパラドックスはどのように起きたのであろう か。著者は幕末維新に英傑を輩出させた吉田松院の『外史』の読みに着眼 する。日本史の何たるかを異論はあったにしろ名文で知るのに山陽外史に 勝る文献はなかった。松陰の取り上げ方の問題は，全文ではなく「尊皇」 と読める箇所を塾生と共に読んでいたということである。山陽の文脈から 
切り離された読解である。松陰的読書に反して, 山陽の執筆意図に則して 山陽を読み実践せんとしたのが松陰と同じく安政の大獄で死罪となった橋 本左内である。左内は松平春㒛に仕え, 家康的名君の可能性を秘めていた 決断できる君主とみた慶喜を将軍にしょうと理論面から画策したのである。 「実用の学」として構想し歴史を踏まえた山陽政治学の現実政治への応用 である。しかし時の「勢」は左内的山陽ではなく松陰的山陽に向かったの である。山陽外史は, 福澤のいう「独立自由の思想なく」であったかもし れない。しかし「漂篎を磨くの考」には終わっていなかった。山陽政治学 が松陰的解釈に向かった所以の展開のさらなる力作を期待したい。

さて山陽がナショナリズムの感情を覚醒させたとした山路愛山も射程に いれ, 北村透谷, 石川豚木, 中里介山という文学で名を成した感性豊かな 人物を政治思想史的視点から丹念に分析したのが小寺正敏『幻視の国家』 である。近代日本における政治（共同体）と文学（個人）の相克を「居場 所探し」として捉えたのである。政治 (天下国家)に挫折し非政治 (文学) に向う透谷は非政治に轁晦できたであろうか。政治（正義・人道・国）に 構うことなく非政治（営利追求）に思いを描いた啄木は煩悶青年から逃れ 得たであろうか。政治（国家・楽土）は非政治（カルマ）から投げ出され た介山を救うことができたであろうか。人間存在をめぐる壮大なドラマの 展開であり，著者の問題意識である。透谷にとって無用視された文学に自 らの道を見出したことの意味は何であったか。「志士仁人」による自由民 権運動から離脱した後, 経世の観念を如何に回復するかが透谷の問題であ った。透谷の文学的営為は政治的見解の表明手段であり,「文字の英雄」は 「兵馬の英雄」と变わる所がない。政治的課題を担う文学の可能性に賭け るのである。論争を引き起こした愛山の山陽論も後継世代に「英雄」を語 る文学の事業性をめぐる問題ではあったが，透谷は文学の結晶たる精神が 思想として結実するとき, 政治的变革を可能たらしめ, 政治と文学は連動 することになるという。明治国家の閉塞状況を突破する「創造的勢力」に 期待し内面から自己同定できる理想の国家の再生を期したと透谷を結論付 ける。啄木については, その思想的変遷をロマン主義 (芸術至上主義), 自 然主義（私生活への逃避）, 社会主義（ユートピア的理想と暴力革命の否 定）の三つの区分に分け，政治意識・国家意識の変遷が論じられる。豚木 は文学を自己表現の課題として投じつつ社会に眼を開き, 生活と文学のジ 
レンマに陥って窮死するに至るという。透谷や啄木と同様に「居場所探 し」においてニヒリズムに陥ったが，介山は聖德太子に出会い，世俗世界 から「逃避せざる生涯」に関心をもち，大乗的菩薩思想に政治と往還をめ ぐる環相のための安心立命を獲得する。『大菩薩峠』もその文脈で検討さ れる。大乗的世界観の展開である。介山の政治的理想は仏教信仰を持って 農業に精励する世界である。「天皇の国にして百姓の国」である日本こそ が農本主義政治思想の到達点であったという。透谷，豚木，介山という文 学者を通して，人間存在の窮極の根拠を喪失した時代に実存の規定として の世界に自ら拠って立つ場「居場所探し」を巡る書ではあるが，しかし 「経世の志」たる公的空間に生きる目的に裏付けられた志の場の探求の書 でもある。「居場所」喪失からの自己探求が国家意識の形成に向かったこ とを本書は根本課題としているのである。志士仁人的な生き方の「居場 所」を定めて安住の場となるべき国家の探求が真摰であればあるほど，楽 土たる国家は虚空の虹の如く，遙か遠くに浮かんだ幻想，即ち「幻視の国 家」であり，彼らの思想的転回過程は近代日本における政治から疎外され た文学青年たちが自己探求を深めて政治に期待を抱きつつ至りついた地点 を示すものであったと結ぶ。情報過多時代にあって国家の幻視化が巧妙に して一層進み，足場を持ち得ない様相を呈している中にあって「居場所探 し」をさせる力作である。

\section{政治史（日本・アジア）}

<評者 奥健太郎 >

対象 村井良太『政党内閣制の展開と崩壊 1927～1936年』 有斐閣, 2014年

井上敬介『立憲民政党と政党改良一戦前二大政党制の崩壊』 北海道大学出版会, 2013年

近年，昭和戦前期の政党政治に関する良書が相次いで公刊されている。 まず取り上げたいのは，村井良太『政党内閣制の展開と崩壊』である。 同書は表題の通り，「昭和初期にひとたび成立した政党内閣制は，なぜ崩壊 したのか」という問いに真摰に向き合った一冊である。

研究史を振り返れば，この問いはこれまで様々な角度から説明が試みら れてきた。例えば，外的環境に注目して，世界大恐慌と対外危機が政党内 閣制の維持を困難にしたとする説明，政党内閣に敵対的な軍部の台頭から 
説明する方法, またあるいは政党の腐敗, 自滅に注目するものもある。こ れらは拉そらく説明として正しい。しかし，問題はそれらがいずれも政党 内閣制崩壊の「背景」しか説明していない点にある。本丸はキャビネット メーカーであった元老西園寺公望，内大臣牧野伸顕であり，彼らが政党内 閣制をどのように考え，なぜその中断を決意したのか，なぜその復活を選 択しえなかった（しなかった）のか，そこに迫らなくてはならない。本書 の真骨頂はそこに真正面から切り込んだところにある。

本書の最大の特色は，前著『政党内閣制の成立 1918～1927』（有斐閣， 2005年）から引き継いだ首相選定の「論理」と「方式」という視点であろ う。この視点から一貫して昭和初期の政党内閣期から中間内閣期までの政 権交代を照射することを通じ，上記の問いへの理論的・包括的な回答を導 きだそうとする分析手法は評価されるべきである。そして，この視点に注 目して同書の内容を紹介するならば，次のようになるのであろう。

大正末期, 唯一の元老となった西園寺は元老の再生産を拒んだが，元老 亡き後の首相選定の仕組みは未確定であった。大正末期には元老・内大臣 協議方式で首相は選ばれたが，いずれ元老は消滅する。となれば内大臣が 首相選定の任を带びるわけだか，選定は高度な政治判断を要するから，内 大臣単独による選定は「宮中府中の別を產す」との批判を招くことが予想 される。そこで西園寺は二大政党による政権交代を半ば機械化しょうとし た。この機械的な政権移動のルールが慣習として確立されれば，内大臣の 政治判断は不要になるのである。そして，それは二大政党による政党内閣 制を理想とする西園寺の思想と適合的なものであった。

西園寺の目指した二大政党による機械的な政権移動は，田中内閣・浜口 内閣期には安定して実行された。浜口が首相に選定されるまでに要した日 数はわずか 1 日, 浜口遭難後の若槻選定の時ですら 2 日である。歴史に if を持ち込むならば，もし世界大恐慌が1929年よりももっと後のことであっ たならば，あるいは当時の中国ナショナリズムがより抑制されたものであ ったならば，西園寺の目指した首相選定のルールは定着し，制度として確 立されたのかもしれない。しかし，1930年代に入ると政党内閣をとりまく 内外の環境は急速に悪化し, 機会的な政権移動は次第に困難になっていた。 若槻内閣が崩壊すると犬養毅が首相に選ばれたが，その際には単独内閣論 の西園寺と協力内閣論の牧野の路線の違いが顕著となり，機械的な選定は 
行いえなかった。さらに五・一五事件が発生すると，首相選定までに 7 日 を要し, 協議には重臣も加えられた。

こうして機械的な首相選定という仕組みが根付かないままご破算になる と，新たな仕組みを考えなくてはならない。西園寺と宮中官僚の協議では， 重臣の範囲，首相選定における重臣の関与の仕方が論点となった。ところ で，政権移動のルールが不明確になると，政党人の頼るべき行動の準則も 失われ，政党の統制が急速に失われた。こうして政党政治が緩慢な崩壊過 程をたどる中，二・二六事件が発生すると，政党内閣復活の可能性はほぼ なくなったのであった。

さて，雑感を記すならば，村井氏の視野の広さにまず圧倒される。評者 にも多少経験があるが，「政党内閣制の崩壊」を論じょうとすれば，政党史 や宮中の政治史はもちろんのこと, 外交史, 経済史, 政軍関係史, 政官関 係史，政治思想史などの様々なフィールドの研究と資料を吸収することが 必要になる。専門分化が進んだ今日，それは決して容易なことではないが， 村井氏は今日までの研究成果を見事に吸収し，相互に融合させながら冒頭 の問いへの回答を導き出している。本書は昭和戦前期政治史研究の一つの 到達点として位置づけられよう。

ただ，長所は短所にも通じる。著者は政党勢力，政党外勢力，首相選 定者，世論・評論の「4 層」に光をあてるが，その表現から分かるように 本書では，様々な政治アクターの多様な動きが，編年史的に詳述される。 そのため中心的な論点がやや見えにくくなっているように感じられた。

次に紹介したいのは，井上敬介『立憲民政党と政党改良』である。従来， 近代政党史研究は立憲政友会を中心に進められてきたが，このところ憲政 会系の研究の進展が著しい。同書は民政党の誕生から解党までを論じた初 の本格的学術書であり，この刊行により憲政会系の政党研究も出揃ったわ けである。

さて民政党の歴史を分析する視点として，著者は「外交政策」と「政党 改良」という二つの軸を設定する。前者は明快で親英米か反英米かという 軸である。後者の軸はやや複雑であるが，著者によれば「官僚主導・国民 を無視した政権本意の軍隊的政党（権力の主体としての資格を欠く政党） から，多数の衆議院議員主導·国民に立脚した政策本位の「立憲政党」（権 力の主体としての政党）に改良すること」と規定される。本書は，この対 
立軸をベースに 3 人の主人公に光を当てている。

一人目の主人公は政党内閣期の中野正剛である。この時期の民政党の政 策決定は英米協調主義の井上準之助，幣原喜重郎，伊沢多喜男ら「党外人」 によって支配され，非英米協調主義の中野ら党人派は除外されていた。そ れでも政党改良の視点で党人派に近かった浜口が健在であるうちは，党外 人と党人派の対立は顕在化しなかった。しかし浜口が倒れたことで両者の 対立は深刻化，協力内閣運動による民政党内閣の自壊へとつながったので あった。二人目の主人公は富田幸次郎である。中間内閣期の富田は，政民 両党を紏合して宇垣一成を党首とする単一保守政党の結成を企図した。富 田は党人派であるが国際協調路線の側である。富田は宇垣新党の結成によ り国際協調路線，政党内閣復帰という道筋を描いたのであった。三人目の 主人公は1935年に総裁に就任した町田忠治である。町田は時代の制約の中 で親英米的な路線で党運営に努めたが，永井柳太郎らの反英米派の挑戦を 受け次第に守勢に立たされた。一方「政党改良」の視点から，町田は政務 調査会の充実などに傾注した。しかし「反軍演説」問題をめぐり総裁とし ての求心力は失われ，民政党は解党へと至ったのである。

このように本書は，二つの軸と 3 人の政党政治家の分析を通じて，民政 党の組織構造を浮き彫りにした注目すべき一冊である。たたし「政党改良」 という軸には疑問が残った。軸はあくまで分析の道具であるから，もう少 し単純さが必要ではなかったか。

ともあれ, 両書の公刊により昭和戦前期政党史研究の水準は一段階引き 上げられた。これまで蓄積された戦前の政党研究が戦後の政党研究と接合 される時，そこにどのような地平が開けるであろうか。日本政治史研究に は大きな可能性が秘められている。

\section{比較政治・政治史（欧米）＜評者 岡山裕>}

対象 三牧聖子『戦争違法化の時代一「危機の20年」のアメリカ国際関 係思想』名古屋大学出版会, 2014年

ジョージ・ケナンが第二次世界大戦前のアメリカの外交姿勢を「法律家 的・道徳家的アプローチ」と呼んで批判したのは，よく知られている。本 稿で取り上げる三牧聖子氏の著作 (以下本書) は，法的・規範的な観点か ら国際政治や対外政策を捉える，この特徵的な認識体組みの形成と退潮を， 
戦間期に登場し同時代人からもラディカルと捉えられた，いかなる戦争も 違法とすべきだと主張する知的・政治的運動を軸に描きだす試みである。 欧米諸国については最近，いわゆる政治の司法化現象への注目もあって， 司法や法曹が政治に与える影響を扱った研究が増加している。またアメリ カでは，近年勢いをつけている法制史学が政治（史）学に刺激を与えてお り，本書はそうした研究上の文脈にも位置づけられよう。

アメリカの平和運動と，それに大きく影響された国際法学は，20世紀転 換期から司法制度の導入による国際紛争の解決や予防に力を入れ始めた。 そこでは，国家連合に起源を持つアメリカの政治的，経済的成功が，合衆 国最高裁判所を頂点とする司法府の存在に負っているとみて，それを国際 政治レベルに応用しょうとするアナロジーが作用したとされる。その中か ら戦争を違法とする考え方が登場し，違法化の条件や範囲が議論になった。 多くの論者が自衛戦争等は合法と捉えたのに対して，条件つきの違法化で はある種の戦争がむしろ推進されかねないという見方から，全戦争の違法 化を提唱したのが，本書の主人公のサマン・レヴィンソンである。

本書の中心は, レヴィンソンを軸に, 戦争の違法化を通じて国際紛争の 解決手段としての武力を克服しょうとした国際法学者, 平和運動家, そし て政策当事者らが戦間期にたたかわせた議論の再構成である。そこからは， 戦争の違法化という考え方が多様かつ有力な政治主体に受け入れられてお り，1928年の不戦条約もこの文脈に位置づけられるのがわかる。他方で， レヴィンソンらも自衛権まで全否定するのにはためらいがあり，また全戦 争の違法化は結局のところ国際政治の現状追認につながる, という難題と 格闘することになった。しかし，有効な処方箋を提示できないままに第二 次世界大戦が始まり，法的・規範的アプローチに取って代わる形で，今日 に連なる現実主義的な国際政治認識が広まっていったのだという。

本書は，同じ戦間期におけるアメリカ国際法学の外交思想との関わりを 扱い，最近英語版が出版された篠原初枝『戦争の法と平和の法』(2003) と 問題関心を多分に共有している。そのうえで，国際法学者にとどまらない 幅広い主体が，法的・規範的認識枠組みを共有しつつも多様な観点から戦 争という「問題」に取りくんだ様子を，等閑視されてきた戦争違法化運動 を焦点に再構築することに成功している。司法裁判所が国内で果たしてき た役割を国際政治に投影するというアナロジーに加え，司法によって平和 
を生みだすのに成功したアメリカには世界全体から戦争をなくす歴史的な 責任がある，という使命感が，この運動を推進した人々に共有されていた という指摘はとくに興味深い。

他方で，著者は戦争違法化運動が抱えた様々な知的限界にも目を向ける。 あるべき国際秩序の像を指し示したアメリカ史について，多くの平和運動 家たちが持っていたイメージは，先住民の排除といった暴力的な側面を捨 象した，歪んだものであった。それと呼応するように，彼らの後押しした 司法裁判所を活用した紛争解決も，法規範を共有できる「文明国」間に射 程が限定されていた。またアメリカが平和愛好的な国家とされた一方で, モンロー・ドクトリンや植民地支配に代表される，他地域との非対称的な 関係には違和感が抱かれなかったことも指摘されている。

もっとも, 本書で戦争違法化運動はご都合主義として描かれているわけ ではない。1930年代に国際秩序への挑戦が活発化するなかで, 現状追認に つながりうる自分達の議論の限界を克服しようとしていたことも強調され ている。それとの関連で，同運動を現実主義と対置する，外交思想史研究 に支配的な二元論は過度の単純化たという立場が，戦争違法化運動への共 感と共に表明される。本書は戦争違法化論のみならず戦間期の外交思想の 全体像に修正を迫る，独創的な成果であり，一定条件下での軍事的制裁が 容認されがちな今日の状況に再検討を促す，問題提起の書としても成立し ている。今後，この分野で篠原の著書と共に参照されていくであろう。

とはいえ，本書に気になる点がないわけではない。本書では，多くの主 体の言説がよく整理されている反面で，各論者がなぜある立場をとったの かについてほとんど説明がなされていない。篠原のように基本的に国際法 学の展開を再構成していたのであれば，それは必要ないかもしれない。し かし，ここでの対象は行政官や政党政治家を含む多様な主体による政治運 動である。彼らの発言はそれぞれに異なる動機付けに基づいてなされてい るはずで，彼らがどんな知的背景や利害に突き動かされていたのかの検討 がなされてもよかったのではないだろうか。この点，本書が外交思想を国 際政治の動向以外からは影響を受けない，自己完結した世界であるかのよ うに扱っているのにはやや違和感をおぼえた。

この論点は, 単なる目配りの広さの問題ではなく, 本書の議論の本質部 分とも関わっている。著者は, 平和運動家を中心に当時のアメリカの論者 
の多く——彼らの多くは法曹であった——が国内法秩序のアナロジーで国 際政治を論じようとしていたのを強調する。にもかかわらず，当のアメリ 力国内法の状況が彼らの考方方をどのように規定しており，それがいかな る提案につながったのかについては，ほとんど具体的な説明がなく，これ はいかにも不自然に思われる。

ひとくちに国際的な司法府を設置するという彼らの主張にしても，裁判 所の形態や役割は地域によって大きく異なる。そのため，アメリカの司法 を念頭に置いていたというだけでは，やや具体性に欠けるように思われる。 例えば，本書の鍵概念の一つである「法による支配」は “rule of law” の訳 だとみられるが，当時のコモン・ローに関する支配的見解では，その実現 が行政機関や行政裁判所などではなく，司法裁判所による審判を要件とし ていたという点を説明しないと，なぜ戦争違法化運動を含む平和運動が司 法裁判所にこだわったのかが十分理解できないのではないだろうか。

さらにいえば，司法裁判所による法執行を掲げる「法による支配」の考 え方は，20世紀転換期以降アメリカ国内で行政機関の活用が本格化するな かで変容を迫られていった。しかも，イリュー・ルート，ウイリアム・H ・タフト, そしてジョン・F・ダレスといった本書の主要登場人物も, そ の過程に深く関わっていたのである。著者がいうように, 戦争違法化運動 家を含む当時の論者達が多分に国内法のアナロジーに依拠していたのであ れば，そこに同時期の国内法の「法による支配」理解とその变化が影響し ていた可能性はないだろうか。例えば，篠原も扱っている「法」と「政治」 の峻別は，国内で行政機関が政治化することなく「法による支配」に則っ た法執行をできるかどうかをめぐる議論に頻出していた。また当時導入さ れた諸規制機関は，1913年に設置された連邦準備制度委員会（FRB）が 「金融界の最高裁」と呼ばれたように, 戦争違法化論者が国際政治について 行ったのと同じく，裁判所のアナロジーで捉えられていたのである。

一時代の外交思想の再構成という本書の課題の大きさを考えれば，さら に国内法までカバーせよというのはないものねだりかもしれない。戦争違 法化運動に光を当てることで, 今日の状況の批判的検討に誘㧍うとする著 者のねらいともずれていよう。それでも, 本書の提起する「国内法のアナ ロジーによる国際秩序理解」の内実をより具体的に検証してみる価值はあ るように思われる。そうした新しい論点を様々に喚起してくれる本書は, 
実に知的に刺激的な一書である。一読を勧めたい。

\section{比較政治・政治史（ロシア・東欧）＜評者 大中 真>}

対象 アンドレス・カセカンプ著, 小森宏美, 重松尚訳『バルト三国の 歴史一エストニア・ラトヴィア・リトアニア 石器時代から現代 まで』明石書店, 2014年

学会誌書評欄の使命が，巷間には知られていない重要書の紹介にあると すれば，本欄で取り上げる著作はまさにそれに該当する。著者は，アメリ カ最古のハーヴァード大学よりさらに 4 年前の1632年に創立されたエスト ニアの最高学府, タルトゥ大学バルト政治学教授のアンドレス・カセカン プである。原書は2010年に刊行されたが (Kasekamp, Andres, A History of the Baltic States (New York: Palgrave Macmillan, 2010))，2010－2011年のバル 卜学会（Association for the Advancement of Baltic Studies）書籍賞を，また 2011年にバルト諸国議員会議の科学部門賞を獲得している。著者と訳者の 協力により，日本語版では2014年までの出来事が反映された最新版となっ ている。カセカンプ教授はまだ40歳代であるが，すでにバルト諸国圈にお いても，また英語圈においても，現代バルト政治史研究の第一人者といっ てよいであろう。

バルト諸国がソ連邦から完全な独立回復を達成したのは1991年 8 月クー デタ事件直後のことであるが，この前の世代のバルト地域の政治学者およ び歴史学者は，ソヴィエト・イデオロギーの制約から逃れることはできな かった。1990年代の体制転換を経て，2000年代に入ってから，欧米諸国で の留学経験を有するバルト各国の若手研究者たちの活躍が顕著になるが, 彼らによりかつての共産主義思想や資料制限からも解放された，真に学術 的なバルト諸国研究が英語圈でも続々と公刊されるようになった。

カセカンプ教授は，1966年に亡命エストニア人の両親からカナダのトロ ントで誕生し，ロンドン大学で歴史学の博士号を取得した後，90年代終わ りにタルトゥ大学に迎えられているので, まさにポスト・ソヴィエト世代 の先頭に立っている。この地において，時代背景と世代によっていかに歴 史家の役割や歴史観が異なるかを分析したものとして，訳者の 1 人である 小森宏美による『エストニアの政治と歴史認識』(三元社, 2009年) がある ので，詳細についてはそちらに譲りたい。 
巻頭でカセカンプ教授自身が述べているように，これまで英語で書かれ

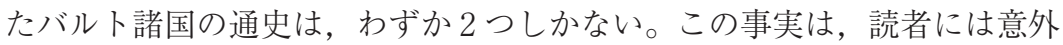
に思われるかもしれない。各国史別，また時代別には，特に20世紀以降の 現代史については，多くの優れた文献が出されている。しかし，本来は民 族的にも言語的にも文化的にも，それぞれ異なる 3 つの国家を 1 つにまと めた通史を書くことは至難の技である。エストニア人歴史学者としてカセ カンプ教授は，「できるだけ同じ分量を三国それぞれについての記述に割 くよう心がけたつもりである」と最初に断っているが，この試みは成功し ているといえよう。

邦題では,「石器時代から現代まで」とされているものの, 実際には分量 の 3 分の 2 は，19世紀以降に割かれている。しかし，バルトの諸民族が， 近代的な意味での民族として自律的に思考し，行動するようになったのは 19世紀半ば以降なので，これは致し方ない。むしろ評価したい点は，長い 間農奴として専制の支配下におかれ，また周辺の大国に蹂躙され続けた弱 小民族として，いわば被害者の立場からの告発的な筆致，もしくは自民族 中心主義的な叙述に陥ることなく，筆者が公平な観点からの歴史を語ろう としている姿勢である（訳者もあとがきで同様に記している）。

評者もかつて，限られた文献の中で，ソヴィエト支配を自己正当化し， ブルジョワ民族主義を敵視し，共産主義の優位を声高く唱えるソヴィエト 史観に基づくバルト人民の歴史書を，また他方で海外に亡命した集団居住 地組織などが発行した，反共思想のプロパガンダと自民族の英雄史観に満 ちた小冊子や資料を，それぞれ見てきたので，カセカンプ教授が本書で成 し遂げようとしたことには共感できる。

その意味でも，本書の真骨頂は，やはり第二次世界大戦を扱った第 6 章 であろう。現在のバルト諸国ではすっかり定着した感のある歴史観である 「3つの占領期」，すなわち独ソ不可侵条約の密約によるソ連邦への併合 (1939－41), 独ソ戦の開始によるナチス =ドイツによる軍事占領（1941－ 1944／45），ソ連邦による再併合（1944／45－1991）の時期である。冷戦の 終結に伴う独立回復後にバルト各国政府が行った精力的な歴史編纂事業に より，多くの悲劇が歴史的事実として裏付けられた。スターリンの命令に より，併合がどのように犯罪的に施行され，どれだけの数の現地人が犠牲 となったか。ヒトラーの命によって，主にリトアニアで，どれほどのユダ 
ヤ人やロマが残虐に殺戴されたか。そしてナチス敗退後に，再占領者とし て戻って来たり連邦国家権力が，報復としていかなる無慈悲かつ凄惨な虐 殺や肃清を繰り返したか。カセカンプ教授は，極力筆致を抑えて淡々と記 述しているがゆえに却って，バルト現代史の真実には戦慄を覚えるほかは ない。

例えば，この第 6 章冒頭にある「本来敵であるソ連またはドイッの軍服 を着て死んでいった」という一節には，第二次大戦の参戦国ではないにも 拘わらず，国家を喪失した民族が，2つの軍事超大国の思惑に翻弄された 様が象徴的に表現されている。スターリン体制下のソヴィエト共産主義と ナチズムという， 2 つの悪のうち，より少ない悪をバルトの人々は選択し なければならなかった。それは，国家を喪失した民族全体としても，また 個々人としても，極めて厳しい体験であった。カセカンプ教授はこの $2 つ$ の悪について，「少なくともナチスによる抑圧や暴力は予測可能であった。 これに対しソヴィエト体制下でのテロルは無原則であった。いっ『人民の 敵』に分類されるか予測がつかなかったのである」と描写している。この 見解は，評者がかつてエストニア人歴史家や外交官たちに訊ねた際の回答 とも概ね一致している。

大戦が終結した後も, 全ヨーロッパ諸国の中でエストニア，ラトヴィア， リトアニアの三国のみが，独立を回復できず，地図上から姿を消した。三 国の人口損失は致命的であり，特にラトヴィアとエストニアでは，人口の ほほ 3 分の 1 が失われた。1953年のスターリンの死によって, バルト地域 でのテロルはようやく収束したものの，ゴルバチョフ政権によるグラース ノスチとペレストロイカ時代まで続いた抑圧と抵抗についても, 続く第 7 章で的確に論じられている。

本書の特徴の一つに, 単なる通史で終わるのではなく, つまり歴代ロシ ア皇帝や為政者の政策や戦争の説明だけでなく, バルト地域の社会構造へ の分析が加えられている点が挙げられる。農奴という「身分」の枠内で生 きてきたバルトの人々が，いかにして自覚と主体性を身につけた「民族」 へと発展していったかを論じた第 4 章は, 社会史の視点からも興味哚く読 むことができる。

独立回復から現在に至る繁栄を描く最終章によって, ようやく読者は安 堵の念を覚えるかもしれない。それほど，バルト諸国の20世紀史は過酷で 
あった。最終節では，所々でロシアに対する厳しい筆致が目につき，読者 にとっては少し思慮が必要かもしれない。しかし個人の研究者によるバル 卜諸国の通史としての，本書の価值を減じるものではない。訳者 2 名によ る翻訳は緻密で読みやすく, 巻末の文献案内も註も充実している。なによ りこのような本格的なバルト諸国に関する通史が日本語で読める時代にな ったことは幸いである。今後しばらく本書は，日本におけるバルト研究入 門の標準書であり続けるだろう。

\section{比較政治・政治史（第三世界）}

＜評者 矢澤達宏 $>$

対象 宮地隆廣『解釈する民族運動 構成主義によるボリビアとエクア ドルの比較分析』東京大学出版会, 2014年

本書は，ボリビアとエクアドルというラテンアメリカの類似性の高い 2 カ国をとりあげ，それぞれの高地，低地で展開された計 4 つの先住民運動 を対象に，その政権獲得行動を構成主義のアプローチにより比較分析をお こない，相違や時系列変化の要因を導き出すものである。これら 4 つの運 動が，いかなる政権獲得行動を，どのタイミングで採用するかを説明しよ うとするとき，同種の命題で常套的に用いられてきた合理的選択論や構造 主義，文化本質主義といったアプローチにはいずれも限界があるとし，環 境や状況，社会や他者との関係などの解釈を通じてつくりだされる規範こ そよりよい説明を提供することが事例分析を通じて示される。ここで，解 釈とはかりに同一のものを対象にした場合であっても人によりその仕方に 相違が生じうるものとして想定され，また解釈が絶えず繰り返されること で，その産物としての規範が同一人物のなかでも時の経過とともに変化す る可能性を織り込んでいることが要諦である。これにより，決定論的・静 的な視点からは逸脱のようにみえる事象も分析の射程に収める余地を生み 出している。

では議論の概要を順に追ってみよう。序章において著者はまず，ラテン アメリカの先住民運動に対し判で押したような画一的な見方がなされがち である傾向に疑問を呈し，先住民運動の多様な姿の探求を問題意識として 掲げる。つづいて 4 運動の政権獲得行動を，選挙を通じた政治参加とクー デターや代替的統治機構の確立といった制度外的権力獲得という2つの夕 イプに類型化した上で，それぞれの運動がどちら（あるいは両方）のタイ 
プに着手したのか，また着手や放衰多イミングがどうだったのかを，政 権獲得行動の異同の判断基準とすることを明示する。これらに照らすと 4 運動間には明白な差異が認められるが，一方でボリビアとエクアドルは政 治経済状況や地理的条件，国際環境など共通点が多い。これを前提に，筆 者は着眼点を先住民を取り巻く諸状況や環境から先住民の内面へと移す必 要性を認識し, 先住民運動の規範によってその政権獲得行動における相違 を説明するという問題設定をおこなう。そして，行動の要因として規範に 着目する構成主義を本書の分析枠組みとして設定することを宣言するので ある。

つづく第 1 章では構成主義アプローチの特徵や意義を示した後，本書の 研究に実際に適用する際の方法や手順が示される。具体的には, 規範の特 定は先住民組織の文書, 関係者の著作やメディアに発表されたインタビュ 一などにおける先住民自身の発言を主たるソースとしておこなうこと，導 出された規範が（周囲の状況・環境よりもそれに対する）先住民自身の解 釈に一義的には拠って立つものであることを立証するため, 各種の対抗仮 説（合理的選択論や構造主義, 文化本質主義の立場からの説明）をも検証 し，説明の妥当性において本書のアプローチには及ばないことを示すとい う手順がとられることなどが提示される。そして，実際に同じ両国の先住 民運動を対象とする先行研究のレビューと, それらの抱える問題点の指摘 がなされる。

第 2 章以下，第 5 章までは第 1 章で示された方法・手順に基づき，実際 の事例分析を各章 1 つずつおこなっている。紙幅の関係上，4つの事例分 析すべてについて十分な要約をおこなうことは困難であるため，代表して 第 2 章をとりあげ，その要旨をもって具体的な議論がどのようなものであ るかの例示としたい。その第 2 章はボリビア高地先住民運動を扱うが，こ の事例では1982年の民政移管前から選挙参加に対する肯定的な規範が存在 してきたことが，1950年代以降の先住民指導者の著作や先住民組織の文書 などをもとに，まずは確認される。実際，1978年の民政移管選挙以降，す べての国政選挙への参加がなされてきたが，一方でこれと並行して80年代 後半から90年代初頭にかけては，ゲリラ組織の活動や既存の統治体制を代 替することを目指す民族議会設立の動きも一部でみられた。こうした制度 外的権力獲得はもともと否定されていたわけではなかったものの, それを 
より積極的に正当化する規範が生じたのは，民政移管後の状況について選 挙を通しても先住民の利益拡大は見込めないと解釈した結果であったと， やはり当事者の発言などから著者は指摘する。しかし，上記の制度外的権 力獲得行動が治安当局による制圧や内部対立などから失敗に終わったこと で，民政移管後の同様の状況に対してもあくまで選挙参加という方向性で 努力を継続すべきと解釈した勢力の規範が，徐々に高地運動全体に受容さ れていったことを運動の展開や著作，新聞等における関係者の発言などか ら著者は跡付けていく。この結果, 選挙を通した政権獲得の試みが継続さ れ，最終的には2005年における先住民候補の大統領当選で宿願成就へと至 る。

第 3 章以降も同様の事例分析が展開される。とくに, 政治経済的文脈の 共通性が高いにもかかわらず，なぜ高地と低地で，あるいはボリビアとエ クアドルで，政権獲得行動に差異が出てくるのか，また両国の高地同士， 低地同士は人口構成比の点で似通っていながら, なぜ行動パターンに相違 がみられるのかを，類似の経験や状況に対する先住民運動による解釈の違 いによって説明していく部分は，本書の真価の見せどころとなっていると いえよう。最後の終章では, 本書の分析結果のまとめとともに, 他の研究 に対し与えうる含意を提示して本書を締めくくっている。

さて，本書の特色にして意義となると，この種の主題に対してはけっし て適用例の多くない構成主義という分析枠組みを採用している新しさ，し かも分析全体を通してそれを貫徹している点をまっさきに挙げぬわけには いくまい。依拠する方法論をあえてサブタイトルで明示していることも， この点に対する著者自身のこだわりの強さをうかがわせる。人間の内面を 组上に載せる分析枠組みは，たしかにある種の曖昧さを孕むことになろう が，著者の言葉を借りれば「解釈」し「自省」する人間像という前提は， より現実味のあるものと感じる。そして実際，本書の議論は全体として説 得力のある妥当な分析であるように評者には感じられた。文字で記録され る範囲を超えた行動の意味を参与観察を通じて見いだしていく人類学の性 格を念頭に，著者は終章において本書を社会科学でありつつも「人類学的 な方向に歩み寄ったアプローチ」と形容しているが，これには目を見開か される思いがした。

新しさがあるとはいえ, 本書で展開されている議論のすべてがこれまで 
まったく未知だったものというわけではなかろう。それは本書でいう規範 や解釈に関わる部分とて，おそらく例外ではあるまい。構成主義を謳って いるか否か,「規範」,「解釈」といった用語を使っているか否かはともかく, 断片的には先行研究においてすでに指摘されていることも少なくないもの と想像する。それでもなお，本書のように単一の枠組みに基づき体系的に 分析してみせることの意義は大きいと考える。なぜなら，規範や解釈とい う要素を織り込んだ枠組みで分析にあたった方が，直感や偶然に任せるよ りも気づきの確率は間違いなく高いと思うからである。本書はそうしたア プローチの有効性を示す根拠の一つとして，また実際に適用する際の手本 の一つとして位置づけられるであろう。

理論的側面にばかり言及すると誤解を招いてしまいそうだが，本書は事 例研究の側面においても遜色のない質の高さを感じさせる。あたかも理論 の妥当性を立証することのみが目的であるかのように，事例のうわべをな ぞっただけという感のある論考をときに目にすることもあるが，本書は少 なくともそうした類とはあきらかに次元が違う。評者は本研究の対象につ いての知識や情報を持たないため，ひとつひとつの事実関係や解釈，評価 の妥当性については判断する術がないが，膨大な数の先住民組織の文書， 声明，機関誌といった一次資料や参照した新聞・雑誌のタイトルを含む, 長大な文献リストを眺めただけでも，やっつけでは到底なしえない仕事で あることは容易に想像できる。

本書のアプローチが盤石，万能というわけでないこともまた，著者自身 も認めるとおり事実であろう。とりわけ，抽出された規範がどの状況や経 験をいかに解釈した結果であるのかという部分の分析については，本書で 提示されたのとは別のとらえ方の可能性もあるように感じられる箇所もあ った。ただ，そうした点をもって本書の価值を減ずるべきではない。規範 や解釈という一筋縄ではいかない人間の内面にあえて向き合い, 白黒はっ きりしないような結果をも恐れずに, 慎重さ, 細心さをもって分析に挑む 姿勢こそ評価されてしかるべきであろう。 


\section{国際関係論}

＜評者 岩間陽子 $>$

対象 ジョン・J・ミアシャイマー, 奥山真司訳『大国政治の悲劇』

改訂版 五月書房, 2014年

Amitav Acharya, The End of American World Order, Cambridge:

Polity Press, 2014

ジョン・J・ミアシャイマーは，ケネス・ウォルツなき後，ネオリアリ ズムを代表するアメリカ政治学界の重鎮である。本書は，2001年に出され た同名の書の改訂版であるが，初版よりはるかに注目を集めている感があ る。この13年間に，中国問題の重みが増したことの証であろう。ミアシャ イマーは自らの理論を，「オフェンシブ・リアリズム」(攻撃的現実主義) と名付けている。彼は，自らを $\mathrm{E} \cdot \mathrm{H} \cdot$ カーやハンス・ J ・ モーゲンソー, ケネス・ウォルツらの系列につらなるリアリストと位置付ける。その中で, 国家をパワーの増大へと向かわせる根源的な理由を，国際社会の構造に求 める点において，ウォルツと同じ「構造的現実主義者」であり，いわゆる 「ネオリアリスト」である。しかし，彼が「ディフェンシブ・リアリズム」 (防御的現実主義)と名付ける従来のネオリアリストと自らを区別するのは, 本質的にアナーキーである国際社会の構造が，国家をどのような行動に向 かわせるかという部分の分析にある。

「ディフェンシブ・リアリスト」たちは，国家の目的は「萛国の生き残り」 にあり，「安全」を求めるため，国家はすでに存在しているパワーを維持 しょうと努力すると考える。それゆえ, 現状維持が大国の最大の戦略目標 となる。これに対してミアシャイマーは，大国の安全を確保する最善の方 法はパワーを最大化することであり，国家は常に「国際システムの中で “唯一の覇権国”（the hegemon）の立場を達成」しょうとする。「国家が自 国の生き残りを確実にしょうとするならば侵略的な行動にでなければなら ない」と考える（p. 55）。しかし，実際に国際システム全体を完全に支配 するような「グローバル覇権国」は今まで存在したことはなく，ある特定 の地理的領域を支配する「地域覇権国」のみが存在したという。水（海） を超えて他地域を軍事的に支配することが，非常に困難であるからだ。

地域覇権を達成した国は，他の大国が同様の地位に就くのを阻止しよう とする。周辺の大国が阻止してくれればいいが，それがうまく行かなけれ ば，遠方の大国が「オフショア・バランサー」となって，必要な処置を施 
す。歴史的には，英米がこの役割を果たしてきた。現状では「世界で唯一 の地域覇権国」はアメリカであり, 今日のアメリカは, この理想的ポジシ ヨンを維持するために行動するはずである（p. 84）。完全な「核武装優越 状態」に支えられた「グローバル覇権国」(単極システム) が不可能である 以上（p. 83），国際システムとしては，二極システムが最も安定する。そ の次に安定するのは，潜在覇権国の存在しない多極システムである。強力 な潜在覇権国を含む「不安定な多極システム（unbalanced multipolarity）」 では，戦争の可能性が高まる（p. 88）。

この理論の正しさを証明するために，彼は1792年から1990年までの大国 の行動を検証していく。そして, 現在のアジアは, 強力な潜在覇権国であ る中国が台頭しつつある, 不安定な多極システムであり, 戦争になる危険 がきわめて高いと分析する。2009年以降の中国の行動は,「中国は平和的 に台頭できない」という彼のテーゼを裏書きしているように見える。アメ リカは，中国が地域覇権国となることを阻止するために，あらゆる手段を 取って周辺国を「バランシング同盟」に巻き込み，「封じ込め」戦略に出る だろうと予測している。しかも，冷戦期のヨーロッパと異なり，潜在的紛 争のシナリオの数が多く，それぞれの軍事力使用のコストは一見低そうに 見えるため，戦争が勃発する可能性がずっと高いという。中国では共産主 義イデオロギーが薄れたものの，「ハイパーナショナリズム」が沸き立って いる。貿易は戦争中でも続くことが多いので, 経済的相互依存は戦争への 防波堤にはならない，と彼は言う。まことに気が滅入る予言だが，オフェ ンシブ・リアリズムの観点から近代国際関係を見るとどうなるか，という ことを詳細に提示してくれた点において，本書の貢献は大きい。邦訳では 脚注がすべて省かれ, 出版社のホームページからダウンロードしなければ ならない点のみ，非常に残念である。

しかし，ナポレオン戦争以来の歴史によって証明されていると称する彼 の理論が，実際現在の世界の分析にどの程度役立つのだろうか。ウクライ ナ紛争も，「イスラム国」との争いも，20世紀までとはかなり異なる様相を 見せている。「歴史はくり返す」と言うが，「同じ戦争は二つとない」とも 言う。近代国家が成立してから，国家と人間を取り巻く状況がいかに激変 して来たかを考えれば，類似性のみに注目するのは危険だろう。また，ミ アシャイマーの分析対象が，欧米大国に偏っていることも，それ以外のア 
クターが急増している現代を分析するのに果たして十分であるか疑問を抱 かせる。

アミタフ・アチャリアは，新著で欧米中心主義から脱する理論構築を試 みている。彼は，「アメリカの世界秩序」，アメリカが率いてきた「リベラ ル・ヘゲモニック・オーダー」が終焉しつつあると考える。ジョゼフ・ナ イは，現在の世界を「複雑な 3 次元のチェスゲーム」になぞらえ，第一次 元は軍事力, 第二次元は経済力, 第三次元が複雑な非国家主体の相互作用 のボードだという。しかしアチャリアは，現在の世界は，一つのシネコン の中で複数の劇場が同時上映しているような，「マルチプレックス・ワール ド」と理解する方がよいという。そのような世界では，アメリカのスクリ ーンも数あるスクリーンの中の比較的大きなスクリーンであるというに過 ぎず，他にも多数の大小の映画が上映されており，観客は自由に見たいも のを選ぶことができる。それでいて，すべてのスクリーンは同一のシネコ ンの中にあるという意味では，ある種の共同体の中にある。大国間コンサ ートによる「多極世界」と違い，観客はより自主性を持って動き，自分の 見たいものを選ぶため，観客とスクリーンの間で相互作用が働く。

このマルチプレックスな世界を理解するには, 高さ, 長さ, 深さに加え て，時間軸を入れた四次元の目が必要である，とアチャリアはいう。全く 同じ形で過去が再現されることは，タイムマシンを発明しない限りあり得 ない。過去に拘束され過ぎては，今起こりつつあることの特殊性を見逃す。 アメリカ主導の「リベラルな秩序」は, 実際のところ冷戦期と1990年代に 世界のごく一部を覆っていただけであり，それが「世界秩序」であったと するのは「神話」であると彼は主張する。そして，「リベラルな世界秩序」 が，実はアメリカのへゲモニーを支える役目を果たしてきたということを， 論証していく。

アメリカがいくばくかの指導力を維持したければ，新興諸国や地域機構 に対して譲歩して，秩序の性格を大幅に変えなければならない。新興諸国 は，一国で世界を支配できるほどの力も，地域覇権国になる力もない。連 携して支配するほどのヴィジョンの一致もない。だからと言って，新興諸 国が唯々諾々とアメリカの秩序に参画するだろうというのは，楽観的すぎ る。彼らは，既存の制度や規範を根底から覆そうとはしないかもしれない が，相当根本的な変更を求めるだろう。結局のところ，グローバル・ガバ 
ナンスのためには，旧「西側」諸国と新興勢力の協力が不可欠になってく る，というのが彼の予言である。一昔前なら，単なる反米主義にしか聞こ えなかったかもしれない主張も含まれているが，第二次大戦後に作られた 多くの国際制度が，ある種の制度疲労を抱えているのは事実であり，広く 世界を見渡せば，分析としても処方箋としても，アチャリアの指摘は説得 力がある。

\section{5年度書評委員会から}

2015年書評委員会のメンバーは，以下の会員にお願いしました(敬称略)。 （1）政治理論：越智敏夫（新潟国際情報大学），（2）政治過程論：佐藤満 (立命館大学),（3）行政学・地方自治：外山公美 (立教大学), (4) 政治 思想史 (欧米) : 佐藤正志 (早稲田大学), （5）政治思想史（日本・アジ ア）：安西敏三 (甲南大学)，（6）政治史（日本・アジア）：奥健太郎（東 海大学)，（7）比較政治・政治史 (欧米)：岡山裕（慶應義塾大学)，（8） 比較政治・政治史（ロシア・東欧）：大中真（桜美林大学），（9）比較政治 ·政治史 (第三世界) : 矢澤達宏 (上智大学), (10）国際関係論：岩間陽子 (政策研究大学院大学)。各委員には, 大変多忙な中，書評委員を扮引き受 けいただき心より感謝を申し上げます。

書評全体を通読すると,「学界に刺激を与えるような業績」「独創的な成 果」「重要な視座を提供するもの」「水準を一段と引き上げるもの」「少し趣 の異なるもの」などの表現もあり，いずれも注目を集めうる図書が選択さ れ，各評者とも力を込めて執筆して頂いたことが分かります。

それにしても，例年のごとく，該当年度中の多くの優れた業績の中から， 限られた冊数の書評対象本を選択することは, 各委員にとって難しい判断 たったと想像されます。書評委員会としては，図書の選択を各委員の判断 に委ねておりますが，各分野で紹介できなかった優れた業績があることも もちろん承知しています。紙幅の関係で，やむなく取り上げることができ なかったことはご寛恕いただきたいと思います。この書評欄が政治学会会 員の研究にとって，貴重な羅針盤であればと祈って，ご挨拶といたします。 (書評委員長 酒井正文) 